\title{
Radiolabelled GLP-1 receptor antagonist binds to GLP-1 receptor-expressing human tissues
}

\author{
Beatrice Waser • Jean Claude Reubi
}

Received: 29 October 2013 / Accepted: 20 December 2013 /Published online: 12 February 2014

(C) Springer-Verlag Berlin Heidelberg 2014

\begin{abstract}
Purpose Radiolabelled glucagon-like peptide 1 (GLP-1) receptor agonists have recently been shown to successfully image benign insulinomas in patients. For the somatostatin receptor targeting of tumours, however, it was recently reported that antagonist tracers were superior to agonist tracers. The present study therefore evaluated various forms of the ${ }^{125}$ iodinated-Bolton-Hunter (BH)-exendin(9-39) antagonist tracer for the in vitro visualization of GLP-1 receptor-expressing tissues in rats and humans and compared it with the agonist tracer ${ }^{125}$ I-GLP-1(7-36)amide.

Methods Receptor autoradiography studies with ${ }^{125}$ I-GLP1(7-36)amide agonist or ${ }^{125} \mathrm{I}-\mathrm{BH}-\mathrm{exendin}(9-39)$ antagonist radioligands were performed in human and rat tissues.

Results The antagonist ${ }^{125} \mathrm{I}-\mathrm{BH}$-exendin(9-39) labelled at lysine 19 identifies all human and rat GLP-1 target tissues and GLP-1 receptor-expressing tumours. Binding is of high affinity and is comparable in all tested tissues in its binding properties with the agonist tracer ${ }^{125}$ I-GLP-1(7-36)amide. For comparison, ${ }^{125} \mathrm{I}-\mathrm{BH}$-exendin(9-39) with the BH labelled at lysine 4 did identify the GLP-1 receptor in rat tissues but not in human tissues.

Conclusion The GLP-1 receptor antagonist exendin(9-39) labelled with ${ }^{125} \mathrm{I}-\mathrm{BH}$ at lysine 19 is an excellent GLP-1 radioligand that identifies human and rat GLP-1 receptors in normal and tumoural tissues. It may therefore be the molecular basis to develop suitable GLP-1 receptor antagonist radioligands for in vivo imaging of GLP-1 receptorexpressing tissues in patients.
\end{abstract}

Keywords Human tumours · GLP-1 receptors · Exendin(9-39) antagonist $\cdot$ Tumour targeting $\cdot$ Peptide receptors

\section{B. Waser · J. C. Reubi $(\bowtie)$}

Division of Cell Biology and Experimental Cancer Research, Institute of Pathology, University of Berne, PO Box 62,

Murtenstrasse 31, 3010 Berne, Switzerland

e-mail: reubi@pathology.unibe.ch

\section{Introduction}

The receptors for the gut hormone glucagon-like peptide 1 (GLP-1) are physiologically expressed in the endocrine pancreas as well as in very large quantities in specific endocrine tumours such as benign insulinomas [1-3]. These receptors have great clinical importance. Indeed, on the one hand, they mediate the action of commercially available GLP-1 analogues such as exenatide or liraglutide to help treat diabetes patients by stimulating their insulin release $[4,5]$. On the other hand, they can be targeted to visualize insulinoma tumours in vivo [6-11]. Available GLP-1-derived drugs for diabetes therapy as well as for insulinoma imaging are agonists. Indeed, for diabetes therapy, the compounds need to efficiently stimulate insulin release, as is also the case with natural GLP-1 [4, 5]. For imaging, current radiolabelled GLP-1 analogues are, thanks to their agonistic characteristics, massively internalized into the tumour cells, providing, as a consequence, a strong imaging signal from the tumour site [12]. This agonist-induced receptor internalization has been shown to be a general feature, not only for GLP-1 analogues, but also for somatostatin, gastrin-releasing peptide (GRP) or cholecystokinin (CCK) [13]. Recently, however, it has been shown in the somatostatin receptor and GRP receptor field that radioligand antagonists, even though they do not internalize, can represent equally good or even better imaging agents [14-16]. Since potent GLP-1 receptor antagonists have been reported [17], it is worth asking whether radiolabelled GLP-1 receptor antagonists may be of use for GLP-1 receptor imaging. While the $\left[\mathrm{Lys}^{40}\left({ }^{111} \mathrm{In}\right.\right.$-diethylenetriaminepentaacetic acid)]-exendin(9-39) antagonist was found unsuitable for in vivo targeting of GLP-1 receptor tissues [12], another radioligand, the ${ }^{125} \mathrm{I}$-Bolton-Hunter $(\mathrm{BH})$-labelled exendin(9-39) antagonist was shown to successfully label pancreatic islets in rats ex vivo [18]. Subsequent work with this radioligand seemed, however, to suggest that the compound was species dependent, with good affinity to rat GLP-1 


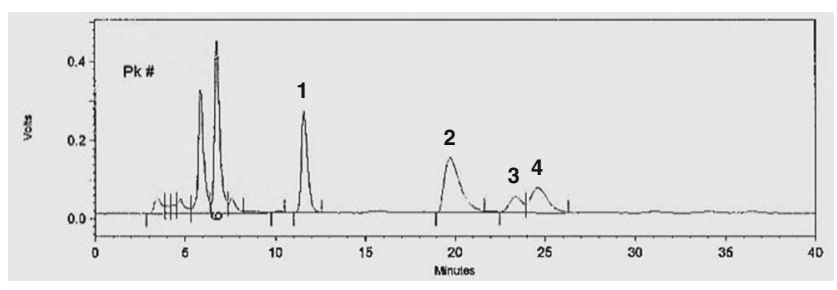

Fig. 1 HPLC of ${ }^{125}$ I-BH-exendin(9-39) showing the various radioactive peaks $1-4$. Specific binding was obtained in peaks 2 and 4 . Peaks 1 and 3 did not bind. Peak 1 represents labelled BH

receptors, but less affinity to human GLP-1 receptors, possibly jeopardizing in vivo imaging of insulinomas in humans [19].

Based on the fact that BH labelling may result in targeting different amino residues of a peptide depending on the labelling conditions, we re-evaluated the binding of the $\mathrm{BH}-$ labelled GLP-1 receptor antagonist with receptor autoradiography in vitro and found that the $\mathrm{BH}$ labelling site is important to obtain a GLP-1 receptor antagonist radioligand binding with high affinity to human GLP-1 receptors expressed in insulinoma and endocrine pancreas.

\section{Materials and methods}

\section{Tissues}

The tissues used were human tumours and human nonneoplastic tissues representing GLP-1 targets, such as endocrine pancreas or duodenal Brunner's glands (see Tables 3 and 4). These tissues, already used in previous studies [2, 19], were collected in accordance with international ethical guidelines, including informed consent and approval by the Institutional Review Board. For control and comparison purposes, we also used normal rat pancreatic, duodenal, lung and thyroid tissues, as reported previously (see Table 3) [2].

Table 1 Binding affinities $\left(\mathrm{IC}_{50}\right)$ for GLP-1(7-36)amide agonist and exendin(9-39) antagonist in binding assays using ${ }^{125} \mathrm{I}-\mathrm{GLP}-1(7-36) \mathrm{am}-$ ide and ${ }^{125} \mathrm{I}-\mathrm{BH}-$-exendin(9-39) (peaks 2 and 4) as radioligands. Tissue: human insulinoma

\begin{tabular}{|c|c|c|}
\hline \multirow[t]{3}{*}{ Tracer } & \multicolumn{2}{|c|}{$\begin{array}{l}\text { Binding affinity } \mathrm{IC}_{50} \\
(\mathrm{nM}) \text { mean } \pm \mathrm{SEM}, n \geq 3\end{array}$} \\
\hline & \multicolumn{2}{|l|}{ Competitor } \\
\hline & $\begin{array}{l}\text { GLP-1(7-36) } \\
\text { amide }\end{array}$ & $\begin{array}{l}\text { Exendin } \\
(9-39)\end{array}$ \\
\hline${ }^{125}$ I-GLP-1(7-36)amide & $3.1 \pm 0.4^{\mathrm{a}}$ & $63 \pm 47^{\mathrm{a}}$ \\
\hline $\begin{array}{l}{ }^{125} \text { I-BH-exendin(9-39) ANAWA peak } 2 \\
\text { antagonist }\end{array}$ & No binding & No binding \\
\hline $\begin{array}{l}{ }^{125} \text { I-BH-exendin(9-39) ANAWA peak } 4 \\
\text { antagonist }\end{array}$ & $1.9 \pm 0.6$ & $13 \pm 1.7$ \\
\hline
\end{tabular}

${ }^{\text {a }}$ Published in [19]
Table 2 GLP-1 receptor density $(\mathrm{dpm} / \mathrm{mg}$ tissue, mean $\pm \mathrm{SEM}, n=3)$ in human pancreatic islets and insulinoma: comparison of different tracers

\begin{tabular}{lll}
\hline Tracer & $\begin{array}{l}\text { Human pancreatic } \\
\text { islets }\end{array}$ & $\begin{array}{l}\text { Human } \\
\text { insulinoma }\end{array}$ \\
\hline $\begin{array}{l}{ }^{125} \text { I-BH-exendin(9-39) ANAWA } \\
\text { peak 2 antagonist }\end{array}$ & No binding & No binding \\
$\begin{array}{c}125 \text { I-BH-exendin(9-39) ANAWA } \\
\text { peak 4 antagonist }\end{array}$ & $1,696 \pm 418$ & $8,093 \pm 1,344$ \\
$\begin{array}{c}125 \text { I-BH-exendin(9-39) PerkinElmer } \\
\text { antagonist }\end{array}$ & $1,925 \pm 696$ & $7,472 \pm 1,061$ \\
\begin{tabular}{l}
125 I-GLP-1(7-36)amide agonist \\
\hline
\end{tabular} & $1,760 \pm 159$ & $7,585 \pm 1,253$ \\
\hline
\end{tabular}

$\mathrm{dpm} / \mathrm{mg}$ disintegrations per minute per milligram

Tracers

(1) The GLP-1 receptor agonist ${ }^{125}$ I-GLP-1(7-36)amide was labelled by Celerion Switzerland AG (Fehraltorf, Switzerland) and purchased at ANAWA Trading SA (Wangen,

Table 3 Comparison of the GLP-1 receptor density in various types of GLP-1 receptor-positive normal tissues using the radiolabelled GLP-1(7-36)amide agonist and ANAWA peak 4 antagonist

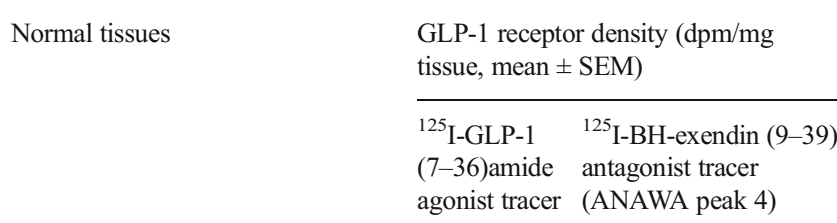

Human

$\begin{array}{lll}\text { Pancreas, } n=5 & & \\ \quad \text { Islets } & 1,482 \pm 192 & 1,470 \pm 313 \\ \text { Acini } & 225 \pm 91^{\mathrm{a}} & 369 \pm 110 \\ \quad \text { Pancreatic ducts } & - & - \\ \text { Brunner's glands, } n=4 & 2,917 \pm 582 & 2,992 \pm 530 \\ \text { Neurohypophysis, } n=3 & 5,274 \pm 805 & 5,583 \pm 799 \\ \text { Leptomeninx, } n=3 & 1,597 \pm 495 & 1,735 \pm 355 \\ \text { Colon (plexus myentericus), } n=3 & 1,056 \pm 34 & 753 \pm 208 \\ \text { Thyroid, } n=3 & - & - \\ \text { Lung, } n=3 & & \\ \quad \text { Parenchyma } & - & - \\ \quad \text { Vessels } & 893 \pm 84 & 588 \pm 148 \\ \text { Rat } & & \\ \text { Pancreas, } n=3 & & \\ \quad \text { Islets } & 4,643 \pm 207 & 4,446 \pm 588 \\ \quad \text { Acini } & 155^{\mathrm{b}} & - \\ \text { Brunner's glands, } n=3 & >10,000 & >10,000 \\ \text { Lung (parenchyma), } n=3 & 7,562 \pm 124 & 7,343 \pm 239 \\ \text { Thyroid, } n=3 & 2,886 \pm 767 & 2,530 \pm 407\end{array}$

$\mathrm{dpm} / \mathrm{mg}$ disintegrations per minute per milligram

a 2 of the 5 samples had acini with undetectable levels of GLP-1 receptor

${ }^{b} 2$ of the 3 samples had acini with undetectable levels of GLP-1 receptor 


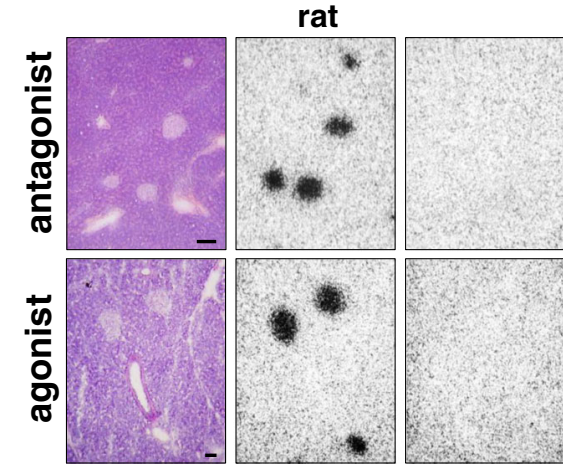

Fig. 2 GLP-1 receptor autoradiography in rat (left panels) and human (right panels) pancreatic islets using the antagonist tracer ${ }^{125} \mathrm{I}-\mathrm{BH}-$ exendin(9-39) ANAWA peak 4 (upper row) or the agonist tracer ${ }^{125} \mathrm{I}$ -

Switzerland). ${ }^{125}$ I-GLP-1(7-36)amide was used as reported before [2]. (2) The GLP-1 receptor antagonist exendin(9-39) was labelled by Celerion Switzerland AG and purchased at ANAWA Trading SA. It was labelled with ${ }^{125} \mathrm{I}-\mathrm{BH}$ and different labelling products were separated by HPLC. The various HPLC peaks obtained were then analysed for binding with autoradiography. Non-radioactive BH-exendin(9-39) was obtained by modification of exendin(9-39) with 3-(4hydroxyphenyl)propionic acid $N$-hydroxysuccinimide ester. Products were separated by HPLC. (3) A commercially available ${ }^{125}$ I-BH-exendin(9-39) antagonist was purchased from PerkinElmer.

\section{Autoradiography}

Autoradiography was performed as reported previously [2, 19], using each of the above-mentioned radioligands, under identical experimental conditions. Briefly, $20 \mu \mathrm{m}$ thick frozen tissue sections were incubated for $2 \mathrm{~h}$ at room temperature in the incubation solution containing $170 \mathrm{mM}$ Tris- $\mathrm{HCl}$ buffer (pH 8.2), $1 \%$ bovine serum albumin (BSA), $40 \mu \mathrm{g} / \mathrm{ml}$ bacitracin, $10 \mathrm{mM} \mathrm{MgCl}_{2}$ and $15,000 \mathrm{cpm} / 100 \mu \mathrm{l}$ of tracer. Nonspecific binding was determined by incubating tissue sections in the incubation solution containing, additionally, $100 \mathrm{nM}$ unlabelled cold GLP-1(7-36)amide (Bachem, Bubendorf,

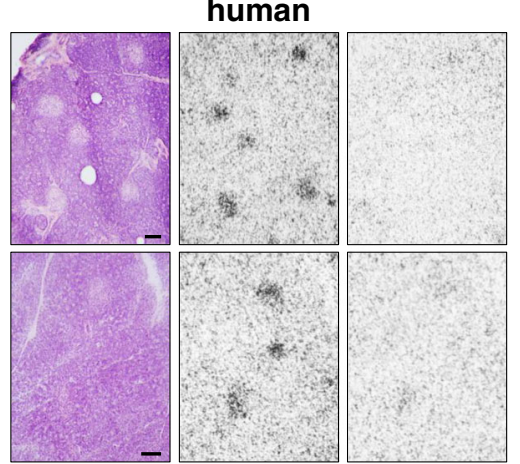

GLP-1(7-36)amide (lower row). Each set represents H\&E staining (left), total binding (middle) and non-specific binding (right). Bars $=1 \mathrm{~mm}$. The rat islets have much more receptors than human islets

Switzerland). Further pharmacological displacement experiments were performed to measure $\mathrm{IC}_{50}$ values using increasing concentrations of the GLP-1 receptor agonist and antagonist. After incubation, the slides were washed five times in icecold Tris- $\mathrm{HCl}$ buffer $(170 \mathrm{mM}, \mathrm{pH} 8.2)$ containing $0.25 \%$ BSA and twice in ice-cold Tris-HCl buffer without BSA. The slides were dried for 15 min under a stream of cold air and then exposed to Kodak BioMax MR ${ }^{\circledR}$ films for 7 days at $4{ }^{\circ} \mathrm{C}$. The signals on the films were analysed in correlation with morphology using corresponding tissue slides stained with haematoxylin and eosin (H\&E). The receptor density was quantitatively assessed using tissue standards for iodinated compounds (Amersham, Aylesbury, UK) and a computerassisted image processing system (Analysis Imaging System, Interfocus, Mering, Germany) [3].

\section{Results}

Radioligand characteristics

For the antagonist radioligand ${ }^{125} \mathrm{I}-\mathrm{BH}-\mathrm{exendin}(9-39)$ (ANAWA), HPLC separated several peaks that were subsequently analysed by receptor autoradiography for binding (Fig. 1). Peak 1 (corresponding to the labelled BH reagent)
Fig. 3 GLP-1 receptor autoradiography in rat (left panels) and human (right panels) duodenal Brunner's gland, using the antagonist tracer ${ }^{125} \mathrm{I}-\mathrm{BH}$ exendin(9-39) ANAWA peak 4 (upper row) or the agonist tracer ${ }^{125}$ I-GLP-1(7-36)amide (lower row). Each set represents H\&E staining (left), total binding (middle) and non-specific binding (right). Bars $=1 \mathrm{~mm}$
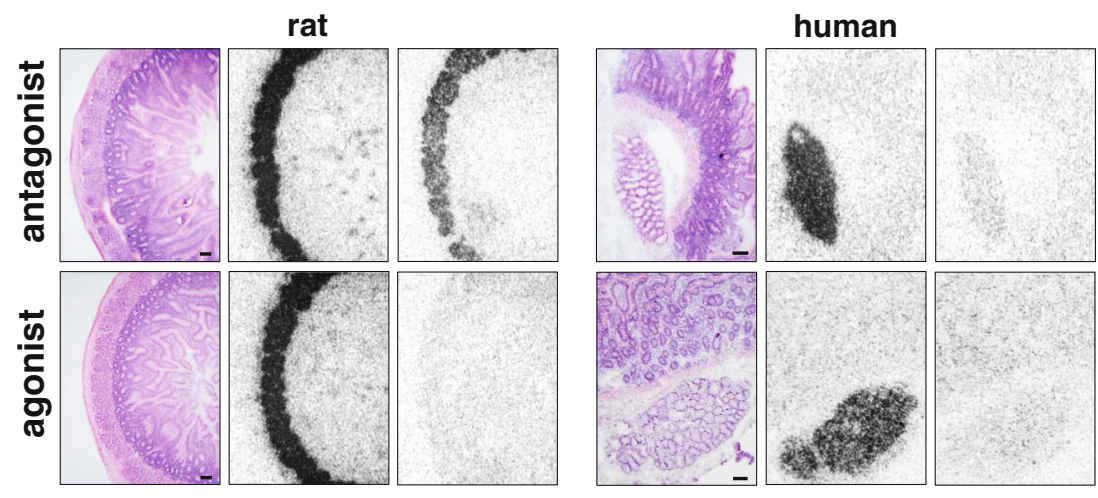
Fig. 4 GLP-1 receptor autoradiography in rat (left panels) and human (right panels) lung and thyroid using the ${ }^{125} \mathrm{I}-$ BH-exendin(9-39) ANAWA peak 4 antagonist. Each set represents H\&E staining (left), total binding (middle) and nonspecific binding (right). Bars $=$ $1 \mathrm{~mm}$

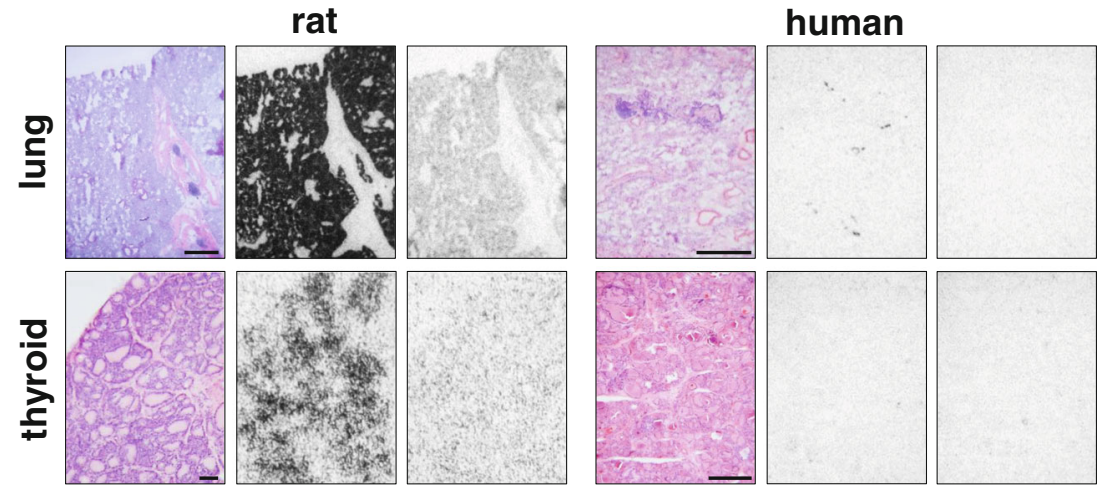

and peak 3 did not bind the GLP-1 receptor. While peaks 2 and 4 bound with high affinity to the rat GLP-1 receptor, it was found that peak 2 did not bind to human tissue (Table 1). Conversely, peak 4 bound with high affinity to human tissue;

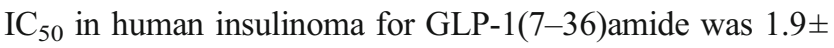
$0.6 \mathrm{nM}$ and for exendin(9-39) $13 \pm 1.7 \mathrm{nM}$. For comparison, the radiolabelled GLP-1 agonist bound to human insulinoma with high affinity as well: $\mathrm{IC}_{50}$ for GLP-1(7-36)amide was $3.1 \pm 0.4 \mathrm{nM}$ and for exendin(9-39) $63 \pm 47 \mathrm{nM}$ (Table 1).

Table 2 shows the density values in human pancreatic islets and human insulinomas using four different tracers: ${ }^{125} \mathrm{I}-\mathrm{BH}-$ exendin(9-39) antagonist ANAWA peaks 2 and 4, commercially available ${ }^{125}$ I-BH-exendin(9-39) antagonist tracer from PerkinElmer and ${ }^{125}$ I-GLP-1(7-36)amide agonist. While ANAWA peak 2 antagonist was negative in these human tissues, ANAWA peak 4 antagonist showed GLP-1 receptor expression in both tissues, with density values comparable to those obtained with the PerkinElmer antagonist tracer and with the GLP-1(7-36)amide agonist tracer (Table 2).

In order to identify the exact sites of $\mathrm{BH}$ labelling in exendin(9-39), the peptide was labelled with non-iodinated $\mathrm{BH}$ reagent by Celerion Switzerland $\mathrm{AG}$ and processed for matrix-assisted laser desorption/ionization (MALDI) mass spectrometry by the ETH Zurich. It showed that BH labelling in peak 2 occurs only on lysine in position 4 , while $\mathrm{BH}$ labelling in peak 4 is predominantly on the lysine in position
19 and, to a lower extent, on lysine in position 4. Therefore, high-affinity binding of peak 4 to human tissues is likely due to the $\mathrm{BH}$ labelling at lysine 19 .

Table 3 compares the GLP-1 receptor density in various types of GLP-1 receptor-positive normal tissues using the radiolabelled GLP-1(7-36)amide agonist and ANAWA peak 4 antagonist. It basically shows that similar values are obtained with both tracers in normal pancreatic tissues, in both humans and rats (Fig. 2). It is worth noting that the rat islets have more GLP-1 receptors than human islets, an observation that is found with both agonist and antagonist tracers; further, the ratio of receptor density between islets and acini is much higher in rats than in humans (Fig. 2). Finally, both tracers show similar receptor densities in other tissues including Brunner's glands (Fig. 3), neurohypophysis, leptomeninx, plexus myentericus of the colon and lung vessels (Table 3). The human lung parenchyma and thyroid are receptor negative with both tracers, while the respective rat tissues have a high density of receptors with both tracers (Fig. 4).

Table 4 shows that both tracers detect similar numbers of GLP-1 receptors in human neuroendocrine and brain tumours. As representative example, Fig. 5 shows GLP-1 receptor autoradiography of an insulinoma, a medullary thyroid carcinoma and a phaeochromocytoma.

Figure 6 is a complete displacement curve in a human insulinoma using ANAWA peak 4 antagonist; it shows the

Table 4 Detection of GLP-1 receptors in human neuroendocrine and brain tumours

\begin{tabular}{|c|c|c|c|c|}
\hline \multirow[t]{2}{*}{ Human tumours } & \multicolumn{2}{|c|}{${ }^{125}$ I-GLP-1(7-36)amide agonist tracer } & \multicolumn{2}{|c|}{${ }^{125}$ I-BH-exendin(9-39) antagonist tracer (ANAWA peak 4) } \\
\hline & $\begin{array}{l}\text { Incidence of GLP-1 } \\
\text { receptor-positive } \\
\text { tumours }\end{array}$ & $\begin{array}{l}\text { Receptor density, dpm/mg } \\
\text { tissue (mean } \pm \text { SEM) }\end{array}$ & $\begin{array}{l}\text { Incidence of GLP-1 } \\
\text { receptor-positive } \\
\text { tumours }\end{array}$ & $\begin{array}{l}\text { Receptor density, dpm/mg } \\
\text { tissue (mean } \pm \mathrm{SEM} \text { ) }\end{array}$ \\
\hline Insulinomas, $n=5$ & $5 / 5$ & $8,575 \pm 1,386$ & $5 / 5$ & $9,455 \pm 1,715$ \\
\hline Medullary thyroid carcinomas, $n=3$ & $3 / 3$ & $1,455 \pm 557$ & $3 / 3$ & $1,376 \pm 558$ \\
\hline Phaeochromocytomas, $n=6$ & $5 / 6$ & $2,593 \pm 355$ & $5 / 6$ & $2,369 \pm 411$ \\
\hline Paragangliomas, $n=5$ & $2 / 5$ & $1,380 \pm 34$ & $2 / 5$ & $1,332 \pm 36$ \\
\hline Meningiomas, $n=7$ & $4 / 7$ & $858 \pm 203$ & $4 / 7$ & $498 \pm 196$ \\
\hline
\end{tabular}

$\mathrm{dpm} / \mathrm{mg}$ disintegrations per minute per milligram 


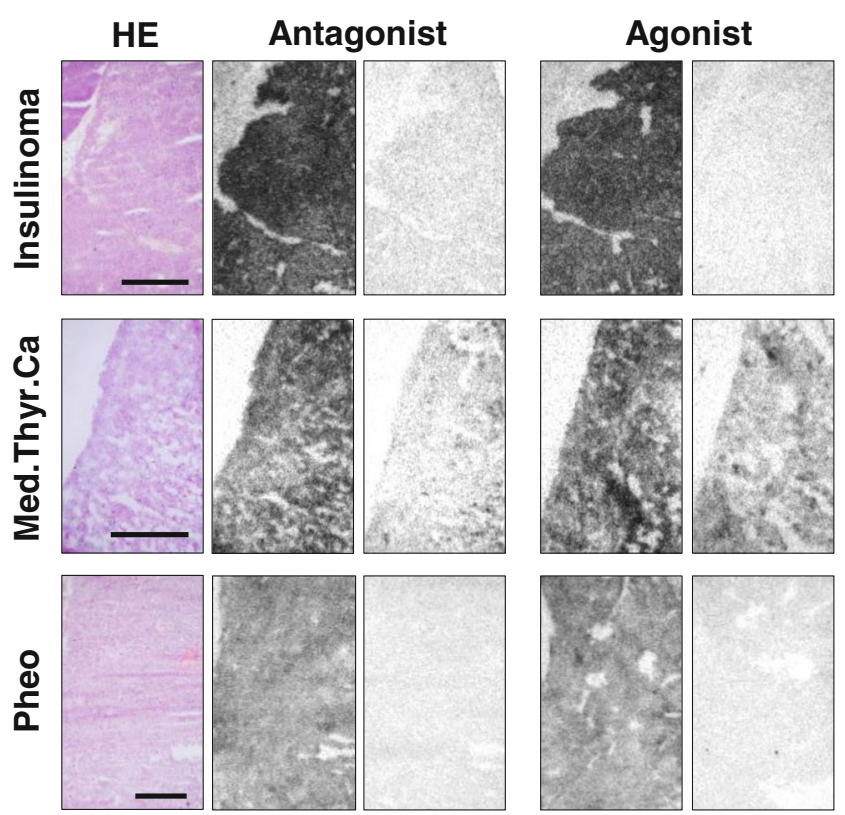

Fig. 5 GLP-1 receptor autoradiography in a human insulinoma, a medullary thyroid carcinoma and a phaeochromocytoma using the antagonist tracer ${ }^{125}$ I-BH-exendin(9-39) ANAWA peak 4 or agonist tracer ${ }^{125} \mathrm{I}$ GLP-1(7-36)amide. Each row shows from left to right: H\&E staining (bars $=1 \mathrm{~mm}$ ), total binding of antagonist, non-specific binding of antagonist, total binding of agonist and non-specific binding of agonist

high affinity displacement by GLP-1(7-36)amide and lower affinity displacement by exendin(9-39), while the unrelated peptide somatostatin 28 is inactive.

\section{Discussion}

Following the recent advances in the somatostatin and bombesin receptor field, documenting that radiolabelled antagonists may be as good or better than agonists for tumour labelling in animals and tumour patients [14, 20], we demonstrate here that a radiolabelled GLP-1 receptor antagonist is

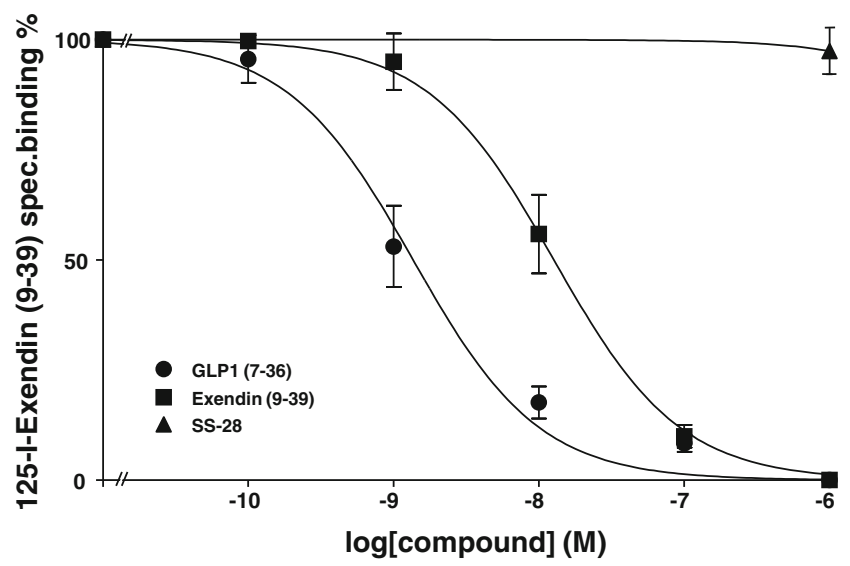

Fig. 6 Displacement curve of ${ }^{125}$ I-BH-exendin(9-39) ANAWA peak 4 antagonist by GLP-1(7-36), exendin(9-39) and somatostatin 28 (SS-28). Mean of $n=3$ experiments able to detect human GLP-1 receptors with high affinity. It also reveals the importance of the BH labelling site of the exendin(9-39) antagonist. Indeed, BH labelling on lysine 19 (ANAWA peak 4) provides a radioligand that is able to detect with similar affinities rat and human GLP-1 receptors, while BH labelling on lysine 4 (ANAWA peak 2) only permits detection of rat GLP-1 receptors.

Our comparative in vivo study shows that both a GLP-1 receptor agonist tracer and a GLP-1 receptor antagonist tracer (with BH labelling on lysine in position 19) are able to label a comparable number of GLP-1 receptors in a large variety of normal and tumoural tissues. This indicates that radiolabelled GLP-1 receptor antagonists could have the potential to become successful GLP-1 receptor markers, in particular for certain human cancers. In the present study, we can further state that the previously observed species difference in GLP-1 receptor expression in rat and human thyroid and lung shown with a GLP-1 agonist [2] is also observed with the GLP-1 receptor antagonist ligand and is therefore a finding independent of the chosen tracers. Of further major interest is the observation of the difference in GLP-1 receptor expression between rat and human pancreatic islets. The rat islets express much more GLP-1 receptors than human islets. Moreover, the rat acini express usually fewer (often even undetectable levels) of the GLP-1 receptors than the human acini, providing an islet to acini ratio of the GLP-1 receptors much higher in rats than in human. This suggests that it could become more difficult to label beta cells in vivo in humans than in rats $[18,21]$.

Interestingly, we do not find a markedly higher amount of labelled GLP-1 receptors with the antagonist tracer compared to the agonist tracer. This is different from recently shown data obtained with somatostatin receptors, where a much larger number of receptors was labelled by a radiolabelled $\mathrm{sst}_{2}$ antagonist than by an agonist, using a similar experimental set-up [22]. At present, the exact reasons (numbers of binding sites, dissociation rate, metabolic stability) why antagonists behave so well in vivo in imaging studies (somatostatin receptor, GRP receptor) are still under debate and will need extensive future investigations. For the moment, the fact that labelling of GLP-1-expressing tumours with the antagonist is excellent provides the chance to develop GLP-1 receptor antagonists for tumour imaging and therapy.

Antagonist compounds may have less side effects than agonists, as observed with radiolabelled GRP receptor analogues [23]. As it is known that GLP-1 receptor agonists used for insulinoma imaging can frequently induce a transient hypoglycaemic effect $[6,11]$, it would therefore be an advantage to use radiolabelled GLP-1 receptor antagonists that do not have this unwanted side effect.

Acknowledgments We thank Drs. Werner Hassler and Ulrich Matthey, Zurich, Switzerland as well as Drs. Charles Pyke and Lotte BjerreKnudsen, Copenhagen, Denmark for helpful discussions. 
Conflicts of interest None.

\section{References}

1. Holst JJ. The physiology of glucagon-like peptide 1 . Physiol Rev 2007;87:1409-39.

2. Körner M, Stöckli M, Waser B, Reubi JC. GLP-1 receptor expression in human tumors and human normal tissues: potential for in vivo targeting. J Nucl Med 2007;48:736-43.

3. Reubi JC, Waser B. Concomitant expression of several peptide receptors in neuroendocrine tumours: molecular basis for in vivo multireceptor tumour targeting. Eur J Nucl Med Mol Imaging 2003;30:781-93.

4. Holst JJ, Vilsbøll T, Deacon CF. The incretin system and its role in type 2 diabetes mellitus. Mol Cell Endocrinol 2009;297:127-36.

5. Drucker DJ, Dritselis A, Kirkpatrick P. Liraglutide. Nat Rev Drug Discov 2010;9:267-8.

6. Wild D, Christ E, Caplin M, Kurzawinski TR, Forrer F, Brändle M, et al. Glucagon-like peptide-1 versus somatostatin receptor targeting reveals 2 distinct forms of malignant insulinomas. J Nucl Med 2011;52:1073-8.

7. Christ E, Wild D, Reubi JC. Glucagonlike peptide-1 receptor: an example of translational research in insulinomas: a review. Endocrinol Metab Clin North Am 2010;39:791-800.

8. Christ E, Wild D, Forrer F, Brändle M, Sahli R, Clerici T, et al. Glucagon-like peptide-1 receptor imaging for localization of insulinomas. J Clin Endocrinol Metab 2009;94:4398-405.

9. Wild D, Mäcke H, Christ E, Gloor B, Reubi JC. Glucagon-like peptide 1-receptor scans to localize occult insulinomas. N Engl J Med 2008;359:766-8.

10. Sowa-Staszczak A, Pach D, Mikołajczak R, Mäcke H, JabrockaHybel A, Stefańska A, et al. Glucagon-like peptide-1 receptor imaging with [Lys40(Ahx-HYNIC- 99mTc/EDDA)NH2]-exendin-4 for the detection of insulinoma. Eur J Nucl Med Mol Imaging 2013;40: 524-31.

11. Christ E, Wild D, Ederer S, Béhé M, Nicolas G, Caplin ME, et al. Glucagon-like peptide-1 receptor imaging for the localisation of insulinomas: a prospective multicentre imaging study. Lancet Diabetes Endocrinol 2013;1:115-22.
12. Brom M, Joosten L, Oyen WJ, Gotthardt M, Boerman OC. Radiolabelled GLP-1 analogues for in vivo targeting of insulinomas. Contrast Media Mol Imaging 2012;7:160-6.

13. Waser B, Tamma ML, Cescato R, Maecke HR, Reubi JC. Highly efficient in vivo agonist-induced internalization of sst2 receptors in somatostatin target tissues. J Nucl Med 2009;50:936-41.

14. Wild D, Fani M, Behe M, Brink I, Rivier J, Reubi JC, et al. First clinical evidence that imaging with somatostatin receptor antagonists is feasible. J Nucl Med 2011;52:1412-7.

15. Cescato R, Maina T, Nock B, Nikolopoulou A, Charalambidis D, Piccand V, et al. Bombesin receptor antagonists may be preferable to agonists for tumor targeting. J Nucl Med 2008;49:318-26.

16. Ginj $M$, Zhang H, Waser B, Cescato R, Wild D, Wang X, et al. Radiolabeled somatostatin receptor antagonists are preferable to agonists for in vivo peptide receptor targeting of tumors. Proc Natl Acad Sci U S A 2006;103:16436-41.

17. Thorens B, Porret A, Bühler L, Deng SP, Morel P, Widmann C. Cloning and functional expression of the human islet GLP-1 receptor. Demonstration that exendin-4 is an agonist and exendin-(9-39) an antagonist of the receptor. Diabetes 1993;42:1678-82.

18. Mukai E, Toyoda K, Kimura H, Kawashima H, Fujimoto H, Ueda $\mathrm{M}$, et al. GLP-1 receptor antagonist as a potential probe for pancreatic beta-cell imaging. Biochem Biophys Res Commun 2009;389: $523-6$.

19. Waser B, Reubi JC. Value of the radiolabelled GLP-1 receptor antagonist exendin(9-39) for targeting of GLP-1 receptorexpressing pancreatic tissues in mice and humans. Eur J Nucl Med Mol Imaging 2011;38:1054-8.

20. Kähkönen E, Jambor I, Kemppainen J, Lehtiö K, Grönroos TJ, Kuisma A, et al. In vivo imaging of prostate cancer using [68Ga]labeled bombesin analog BAY86-7548. Clin Cancer Res 2013;19: 5434-43.

21. Connolly BM, Vanko A, McQuade P, Guenther I, Meng X, Rubins $\mathrm{D}$, et al. Ex vivo imaging of pancreatic beta cells using a radiolabeled GLP-1 receptor agonist. Mol Imaging Biol 2012;14: $79-87$.

22. Cescato R, Waser B, Fani M, Reubi JC. Evaluation of 177Lu-DOTAsst2 antagonist versus 177Lu-DOTA-sst2 agonist binding in human cancers in vitro. J Nucl Med 2011;52:1886-90.

23. Bodei L, Paganelli G, Mariani G. Receptor radionuclide therapy of tumors: a road from basic research to clinical applications. J Nucl Med 2006;47:375-7. 